\title{
LEGAL PROTECTION FOR TRADITIONAL KNOWLEDGE
}


This page intentionally left blank 


\section{LEGAL PROTECTION FOR TRADITIONAL KNOWLEDGE}

Towards a New Law for Indigenous Intellectual Property

ANINDYA BHUKTA

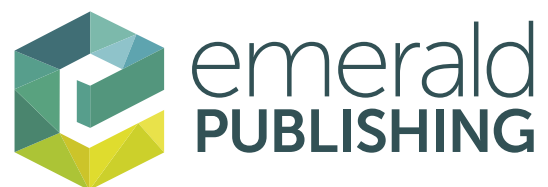

United Kingdom - North America - Japan - India Malaysia - China 
Emerald Publishing Limited

Howard House, Wagon Lane, Bingley BD16 1WA, UK

First edition 2020

Copyright (C) 2020 Emerald Publishing Limited

Reprints and permissions service

Contact: permissions@emeraldinsight.com

No part of this book may be reproduced, stored in a retrieval system, transmitted in any form or by any means electronic, mechanical, photocopying, recording or otherwise without either the prior written permission of the publisher or a licence permitting restricted copying issued in the UK by The Copyright Licensing Agency and in the USA by The Copyright Clearance Center. Any opinions expressed in the chapters are those of the authors. Whilst Emerald makes every effort to ensure the quality and accuracy of its content, Emerald makes no representation implied or otherwise, as to the chapters' suitability and application and disclaims any warranties, express or implied, to their use.

British Library Cataloguing in Publication Data

A catalogue record for this book is available from the British Library

ISBN: 978-1-80043-066-2 (Print)

ISBN: 978-1-80043-063-1 (Online)

ISBN: 978-1-80043-065-5 (Epub)

ISOQAR certified

Management System

awarded to Emerald

for adherence to

Environmental

standard

ISOQAR

ISO 14001:2004.

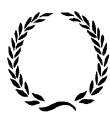

INVESTOR IN PEOPLE 
my wife

source of my inspiration 
This page intentionally left blank 


\section{CONTENTS}

Preface

1. Introduction

1.1 The Prelude

1.2 The Problem We Are Facing

1.3 Rationale Behind the Study

1.4 The Gaps We Found 12

1.5 Our Objectives 13

2. Traditional Knowledge: An Overview 15

2.1 Definition of Traditional Knowledge 15

2.2 Different Dimensions of Traditional Knowledge and Their Uses

2.2.1 Traditional Knowledge on Agriculture 18

2.2.2 Traditional Knowledge on Medicine 18

2.2.3 Traditional Cultural Expressions 20

2.3 Economic Importance of Traditional Knowledge 21

2.4 Argument for Protecting Traditional Knowledge 22

2.5 Traditional Knowledge in International Fora 27

2.5. 1 International Milestones in

Safeguarding Traditional Knowledge 27

2.5.2 The International Union for the Protection of New Varieties of Plants 28

2.5.3 Food and Agriculture Organization 31

2.5.4 World Intellectual Protection

Organization WIPO 
3.2 Economic Impacts of Bio-piracy 46

3.2.1 A Threat to Food Security 50

3.2.2 A Threat to Health Security 54

3.3 Case Histories of Bio-piracy in India 57

3.3.1 The Case of Turmeric 57

3.3.2 The Case of Neem 58

3.4 Case Histories of Bio-piracy in Other Countries 59

3.4.1 The Case of Ayahuasca 59

3.4.2 The Case of Enola Bean 61

3.5 Access and Benefit Sharing Mechanism 62

3.5.1 Bonn Guidelines 64

3.5.2 The Nagoya Protocol 66

3.6 Examples of Access and Benefit Sharing over the Countries

68

3.6.1 Examples of Access and Benefit

Sharing in India

3.6.2 Examples of ABS in Other Countries

4. Protecting Traditional Knowledge: Ways and Means

4.1 What Is Intellectual Property? 73

4.2 Protecting Intellectual Property Right 73

4.3 Alternative Ways to Protect Traditional Knowledge 74 4.3.1 Positive protection $\quad 75$

4.3.2 Defensive protection 76

4.4 Positive Protection via Intellectual Property

Rights Laws

78

4.4.1 Patent $\quad 78$

4.4.2 Plant Patent 79

4.4.3 Geographical Indication 80 
4.4.4 Copyright 81

4.4.5 Trademark 84

4.4.6 Trade Secrets 85

4.5 Defensive Protection 87

4.5. 1 Documentation of Codified Traditional Knowledge in India 87

4.5.2 Traditional Knowledge Databases of Other Countries

4.5.3 Documentation of Non-codified Traditional Knowledge: Initiatives in Different Countries

5. Initiatives to Protect Traditional Knowledge 97

5.1 Introduction 97

5.2 Initiatives in India 98

5.2. 1 Patent Act of India 98

5.2.2 Geographical Indications of Goods (Registration and Protection) Act, $1999 \quad 106$

5.2.3 Copyright Act, $1957 \quad 107$

5.2.4 Biodiversity Act, $2002 \quad 108$

5.2.5 Protection of Plant Varieties and Farmer's Rights Act, 2001 (PPVRA, 2001) 111

5.2.6 The Seeds Bill 116

5.3 Initiatives in Other Countries 118

5.3.1 The Philippines 118

5.3.2 Panama $\quad 120$

5.4.1 Africa 122

6. How Fit Are the Existing Intellectual Property Rights Laws in Protecting Traditional Knowledge? 125

6.1 Introduction 125

6.2 Limitations of Patent 126

6.3 Limitations of Plant Patent 127

6.4 Limitations of Copyright Act 128

6.5 Limitations of Geographical Indication Act 133 
6.6 Limitations of Trademark 135

6.7 Limitations of Trade Secrets 136

7. Towards a New Law 139

7.1 Introduction 139

7.2 The Model Law 142

$\begin{array}{ll}\text { Notes } & 149\end{array}$

References $\quad 155$

$\begin{array}{ll}\text { Index } & 167\end{array}$ 


\section{PREFACE}

Misappropriation of different types of traditional knowledge of different countries is, nowadays, a thriving business and hence a great challenge to the developing world, especially to the developing countries of the Southern hemisphere. The aboriginal communities of these developing countries, who possess this knowledge, are getting deprived as a result. The multi- national companies of developed countries, who are especially misappropriating this knowledge, neither recognize the contribution of these people, nor do they share the benefits arising out of the commercial use of this knowledge with these people. All these can happen due to the absence of any appropriate law to protect this valuable knowledge base. Presently different countries are trying to prevent these misappropriations with the help of existing intellectual property rights laws. Some sui generis laws have also been developed. But the problem is that most of these initiatives consider a particular dimension of this multi-dimensional knowledge suited to their objectives. What is happening as a result is that very often these laws are becoming overlapping and contradictory. To overcome this problem what is the need of the hour is to develop a comprehensive law which will encompass all the dimensions of traditional knowledge.

The objective of the present study, 'Legal Protection for Traditional Knowledge: Towards a New Law for Indigenous Intellectual Property' is to find out the lacunas of the present 
legislative structure and to propose the outlines of a law, its objectives and provisions that could protect the rights of the traditional knowledge holders. Accordingly, the study defines the term traditional knowledge, addresses its different dimensions and explores the economic importance of this knowledge. How this issue is addressed in different international and national forums, how different existing IPR laws try to protect the rights of knowledge-holders, what initiatives are taken by different countries - all such issues are discussed in the present treatise. The study also explains the limitations of existing laws in this regard. Finally, on the basis of the above analysis, a sui generis law - what should be the objectives of the law, what provisions should be included in the law - has been suggested.

The present work is the outcome of my decade-long study on different issues on intellectual property rights. It's my great pleasure that a renowned publishing house like Emerald Publishing Limited has come forward to bring my work to the notice of the world of intellectuals. I would always be indebted to all the family members of Emerald, especially to Nick Wolterman, who extended immense support to me throughout this journey with Emerald. I would also like to convey my sincere gratitude to Professor Sebak Kumar Jana of Vidyasagar University, West Bengal, for his valuable suggestions in completing the work. Above all, I must acknowledge the fact that the work would not have started at all if Professor Raj Kumar Sen had not been there to literarily insist on my serious pursuit of the project. Professor Sen is no longer among us. I shall feel his absence once more when this book finally sees the light of the day.

Anindya Bhukta

Arambagh

January 25, 2019 